John Carroll University

Carroll Collected

Biology

$5-2011$

\title{
Geologic composition influences distribution of microbiotic crusts in the Mojave and Colorado Deserts at the regional scale
}

Rebecca E. Drenovsky

John Carroll University, rdrenovsky@jcu.edu

Nicole Pietrasiak

Jeffrey R. Johansen

John Carroll University, johansen@jcu.edu

Follow this and additional works at: http://collected.jcu.edu/biol-facpub

Part of the Biology Commons, and the Plant Sciences Commons

\section{Recommended Citation}

Drenovsky, Rebecca E.; Pietrasiak, Nicole; and Johansen, Jeffrey R., "Geologic composition influences distribution of microbiotic crusts in the Mojave and Colorado Deserts at the regional scale" (2011). Biology. 17.

http://collected.jcu.edu/biol-facpub/17

This Article is brought to you for free and open access by Carroll Collected. It has been accepted for inclusion in Biology by an authorized administrator of Carroll Collected. For more information, please contact connell@jcu.edu. 


\title{
Geologic composition influences distribution of microbiotic crusts in the Mojave and Colorado Deserts at the regional scale
}

\author{
Nicole Pietrasiak*, Jeffrey R. Johansen, Rebecca E. Drenovsky \\ Biology Department, John Carroll University, 20700 North Park Blvd. University Heights, OH 44118, USA
}

\section{A R T I C L E I N F O}

\section{Keywords:}

Algae

Biological soil crust

CCA

Lichen

Granitic soils

Disturbance

\begin{abstract}
A B S T R A C T
Abiotic and biotic factors influencing distribution of microbiotic crusts within hot deserts, such as the Mojave and Colorado Deserts, are poorly known. Our objective was to examine microbiotic crust distribution with reference to soil and parent material characteristics as well as plant functional groups in wilderness areas of Joshua Tree National Park (JTNP). A total of 75 sites were visually assessed for crust abundance and plant community composition; soil physical and chemical factors also were measured. Microbiotic crusts of JTNP, in particular lichen and moss crusts, were not as well-developed or as widely distributed as in other arid regions of North America. Algal crusts were most prevalent, lichen crusts were sparse, and crusts containing mosses were rare, with average percent land surface absolute (and relative) cover for these three cover categories being $11.4 \%$ (17.4\%), $1.7 \%(2.7 \%)$, and $0.02 \%(0.02 \%)$, respectively. Previously reported individual drivers of crust development, such as $\mathrm{pH}$, electrical conductivity (EC), and soil texture, did not appear to strongly influence crust development in this study of the Mojave and Colorado Deserts. Proximity to granitic bedrock and grusy granitic soils associated with it were the key determinants of microbiotic crust distribution in the wilderness areas of JTNP. In particular, crusts were best developed in grusy granitic soils. Overall, our study emphasized the importance of geology in driving crust distribution and its potential value as a predictor of where crusts may occur in the hot deserts of North America.
\end{abstract}

\section{Introduction}

Worldwide, microbiotic crust communities serve important ecological roles in vegetation-sparse arid and semiarid environments (see reviews of Evans and Johansen, 1999; Belnap et al., 2001; Belnap and Lange, 2003). Much is known about their functions in soil stabilization, water relations, fertility, and organic matter accumulation, as well as their ability to provide habitat for reptiles and invertebrates, and their positive and negative effects on vascular plant seedling establishment (West, 1990; Johansen, 1993; Evans and Johansen, 1999; Belnap et al., 2001; Johansen and Schubert, 2001; Shepherd et al., 2002; Zaady and Bouskila, 2002; Darby et al., 2007). Crust function is tied to crust morphology and composition, and these variables vary greatly between climatic regions (see reviews of Johansen, 1986; West, 1990).

Many studies have examined relationships between environmental variables and crust composition and cover to determine

\footnotetext{
* Corresponding author. Present Address: Soil and Water Sciences Program, Department of Environmental Sciences, 2258 Geology Building, University of California, Riverside, Riverside, CA 92521, USA. Tel.: +1 9518273711.

E-mail address: npiet001@ucr.edu (N. Pietrasiak).
}

which variables most influence crust development. Overall, climatic, edaphic, geomorphic, and anthropogenic factors are important drivers affecting crust establishment, distribution and composition (see Belnap et al., 2001; Belnap and Lange, 2003 for reviews). In the absence of disturbance, a number of abiotic factors have been implicated as important for crust development, primarily soil texture, pH, and electrical conductivity (Belnap et al., 2001, 2003). Fine-textured soils with neutral to slightly alkaline $\mathrm{pH}$ and elevated electrical conductivity seem to foster the best crust development (Anderson et al., 1982a,b; Belnap, 2002; Johansen et al., 2001; Lalley and Viles, 2006; Thompson et al., 2006).

In the United States, extensive ecological crust research has been conducted in the cold deserts (Great Basin, Colorado Plateau; see Belnap and Lange, 2003 for reviews), but little is known about microbiotic crust ecology in the drier, hot deserts (e.g., Mojave and Sonoran Deserts), where crusts are patchy in distribution. Moreover, most researchers have investigated sites with established microbiotic soil crust or areas supporting crust prior to anthropogenic disturbance. Desert landscapes of the arid southwest have been impacted by various human activities, including mining, grazing, and military activities. However, even within these landscapes are gradients of disturbance (Johansen et al., 2001), with 
some remote sites experiencing relatively low levels of humancaused disturbance (e.g., Belnap et al., 2007b). Comparisons of relatively undisturbed uncrusted and crusted soils are lacking, and the limits which preclude crust development remain unknown. In one of the few studies conducted in the Mojave Desert, microbiotic soil crusts were only 5-15 mm thick, less developed and patchier in distribution compared to those found in cold deserts (Johansen et al., 2001). In this study, sites varying in their documented human impacts were included (e.g., intensively disturbed, moderately disturbed, and relatively undisturbed) to study the relative influence of disturbance on crust development. Although disturbance intensity was the primary predictor of crust development, some relatively undisturbed areas did not develop crusts. Overall, it is unclear how abiotic factors influence microbiotic crust development in the hot deserts of North America.

Preliminary studies of spatially restricted areas within Joshua Tree National Park (JTNP) indicated that microbiotic soil crusts were visually abundant in some areas and absent (no consolidation of soil surface particles) in others (Pietrasiak, 2005; Řeháková et al., 2007). It became evident that a larger survey area would be needed to elucidate which environmental factors affect crust distribution in the park. Consequently, we initiated a study that included visually crusted and uncrusted soils that varied in their historical disturbance intensities from moderate (in a few concentrated areas in the northwest and south of the park area) to low disturbance (most of the park area). Joshua Tree National Park is well suited to such a study as it consists mostly of wilderness land, includes eight different plant communities, and represents two hot deserts, the southern part of the Mojave Desert and the Colorado Desert (the northernmost reach of the Sonoran Desert). Additionally, much of the park has been federally protected since 1936, limiting anthropogenic disturbance at our study sites for over the past 70 years (Greene, 1983).

Our primary goal for this study was to understand the factors driving the distribution and abundance of microbiotic crust in the hot deserts of Joshua Tree National Park. Our objective was to ecologically assess microbiotic crust distribution and abundance throughout the Park's wilderness areas by studying the relationship between biotic and abiotic variables with crust distribution and development. Based on studies conducted in the other, colder North American Deserts, we expected the best crust development in areas with fine-textured soils, alkaline $\mathrm{pH}$, and elevated electrical conductivity.

\section{Materials and methods}

\subsection{Site description}

Joshua Tree National Park (JTNP) is located in central southern California $\approx 225 \mathrm{~km}$ east of Los Angeles in between Interstate 10 and Highway 62, encompassing parts of Riverside and San Bernadino Counties. Approximately 325,000 ha of parkland span over two deserts, the southern part of the Mojave Desert and the northern Colorado Desert (Fig. 1). Elevation ranges from $\approx 163$ to $1524 \mathrm{~m}$. The climate is arid; mean average annual precipitation is approximately $120 \mathrm{~mm}$ (http://www.wrcc.dri.edu/summary/Climsmsca.html) with most precipitation falling in the winter months and minimal amounts during the summer (MacMahon and Wagner, 1985). However, annual precipitation events are highly variable, both temporally and spatially (Osborn, 1983). The higher elevation Mojave Desert occasionally receives snow events during the winter (http://www.nps.gov/jotr).

\subsection{Land use}

For the past 5000 years human have occupied and used the land of JTNP infrequently. No archeological records suggest a permanent occupation by Native American tribes in the early millennia (Greene, 1983). Until the 1840s the area of JTNP was traveled only marginally, when American pioneers arrived. During this time mining activities were initiated; approximately 300 mines were built in the JTNP mountains, but most were abandoned in the early 20th century due to their inefficiency (Greene, 1983, www.nps.gov/jotr).

As a result of mining, roads were improved and extended, making these desert lands appealing to ranchers and settlers, particularly in the regions northwest and south of today's park boundary. Ranching activities peaked in 1920 and declined afterwards. In 1936, cattle grazing declined and was mostly eliminated when President Roosevelt declared 825,340 acres of Joshua Tree a National Monument. In 1950, parkland was decreased by 265,000 acres for mining purposes, but was re-expanded in response to the Wilderness Protection Act of 1964. In 1976, Congress designated 420,000 acres in

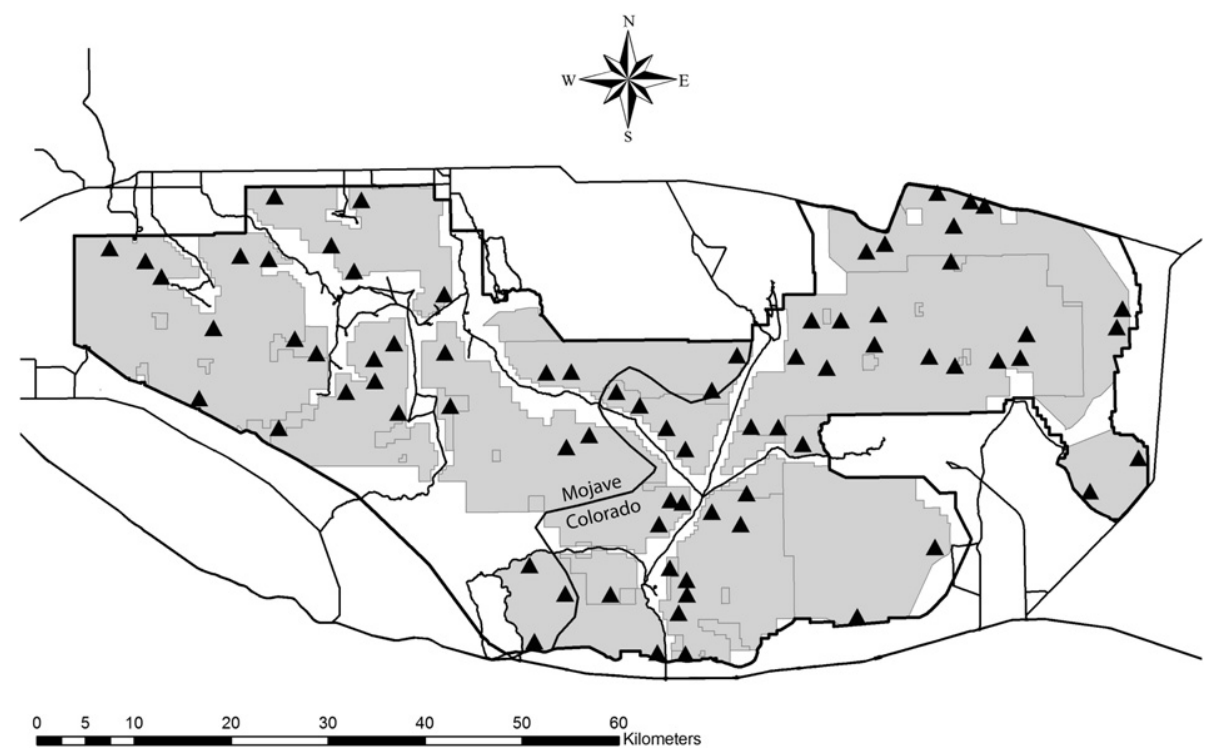

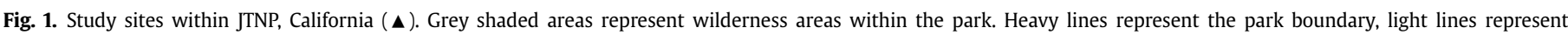
major roads. 
Joshua Tree National Monument as wilderness land, and in 1994 Joshua Tree National Monument was changed to Joshua Tree National Park under the Desert Protection Bill. With this declaration, 234,000 acres were added bringing the total wilderness area in the park to 585,000 acres (www.nps.gov/jotr). This historical protection makes JTNP ideal for a survey of where crust potentially can occur.

\subsection{Field methods}

Within JTNP, there are twelve wilderness areas comprising 237,000 ha. We established 75 sites within the park by placing points on a topographic map; these sites represented all 12 wilderness areas and maximized dispersion of sites within in the park (Fig. 1). Sites were placed at least $2 \mathrm{~km}$ away from any roads to minimize human disturbance effects at our sites. UTM coordinates from these map points were transferred into mobile GPS units to locate the field sites. This approach removes potential investigator bias and allows more accurate estimation of crust cover. We sampled both visually crusted and uncrusted sites to determine the factors favoring development as well as those factors precluding crust formation. Steep, rocky mountainous slopes were excluded from our study due to the logistical difficulty in sampling such sites and the paucity of soil (and thus microbiotic crusts) found in such terrain. Fieldwork was conducted between 23 May and 16 August 2007.

We included 75 intensively studied sites and an additional 140 sites that were only visually assessed for crust cover. At each intensively studied site, three parallel $50 \mathrm{~m}$ transects were established. For consistency, transects were placed perpendicular to the direction of major water runoff, with each transect being approximately $20 \mathrm{~m}$ apart from each other (See Fig. 2 for sampling scheme). A total of 100, $1.0 \mathrm{~m}^{2}$ plots were placed at the outer transects (50 per transect), and were scored for visual presence/absence of total crust, algal crust, lichen crust, moss crust, mixed crust (algal crust with lichen or moss thalli smaller than $1 \mathrm{~cm}^{2}$ ), woody shrubs, cacti, perennial plants, rocks, and boulders/bedrock (Fig. 2). Percent frequency was determined as the percent presence in these 100 plots. In addition, the developmental stage of the algal crust was recorded in the percent frequency plots as incipient crust, unblackened algal crust, and blackened crust. For the topsoil to be called crust, some degree of consolidation and evidence of fine filaments was required. Incipient crust was defined as crust, which had weak soil consolidation, but still some indication of fungal hyphae or algal filaments, and could

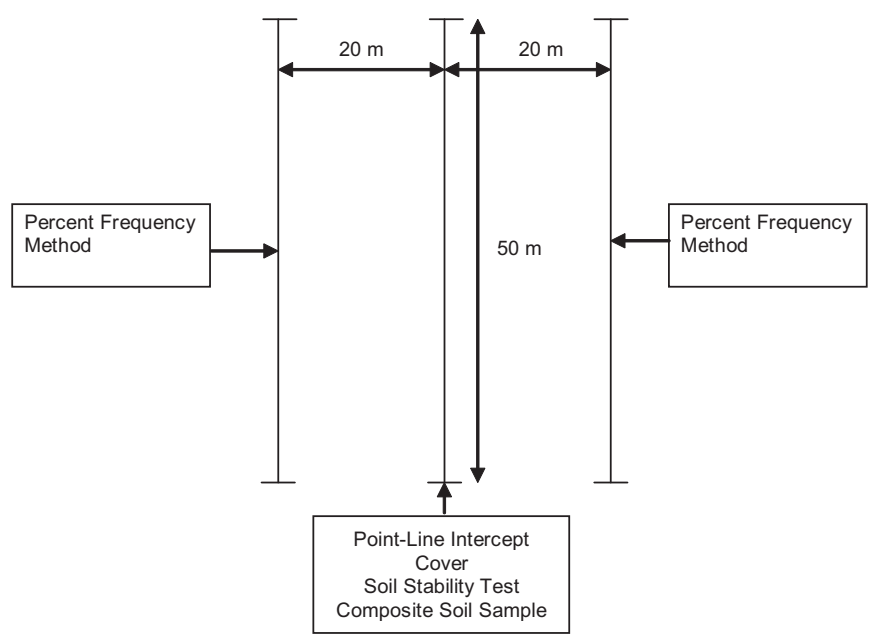

Fig. 2. Sampling scheme showing three parallel transects, with the outer two used for 50 frequency quadrats each, and the inner transect used for 250 points for determination of percent cover. Stability tests and soil samples were taken from the central transect. break very easily by shaking. Unblackened algal crust was defined as having good consolidation, which did not break easily by mechanically shaking and showing visible evidence of filaments. Blackened algal crust was the best-developed algal crust stage showing a darkening of the topsoil surface. In this study, we recognize that cyanobacteria are the dominant components of algal crusts of this region (Johansen et al., 2001), but we will refer to all cyanobacterialdominated crusts as algal crusts, as we did not confirm microbial composition with microscope analysis. Lichen crusts were subcategorized into cyanobacterial and green algal lichen crusts, and lichen species were recorded. Woody shrubs and cacti were recorded by species, and perennial plants were subcategorized as grasses or forbs. These data were later used to characterize the plant communities surveyed.

Using the point-line intercept method, we estimated absolute ground cover of the following biotic and abiotic categories: total crust, algal crust with developmental subcategories, lichen crust with subcategories, moss crust, mixed crust, woody shrubs by species, cacti by species, annuals, perennial forbs and grasses, rocks, pebbles, gravel, litter and bare soil. All abiotic and biotic land surface cover categories found in the landscape were considered equally important. With this landscape approach we objectively characterized how much of the entire land surface was covered by microbiotic crust and how much was explained by the other ecosystem components (e.g., vascular plants, gravel, rocks etc.). Thus, these values are lower than if we had only considered the portion of the soil surface available for crust establishment. For comparison purposes with other literature on desert crusts, we also calculated relative crust abundance, which takes into account the proportion of land surface potentially available for crust development (i.e., excluding areas of physical land surface components such as gravel, cobbles, rocks and boulder). A total of 250 points were read in the center transect (every $20 \mathrm{~cm}$ on the transect) to score these variables.

Soil stability ( 9 replicates for each site by depth combination taken along the center transect) was determined at each site by removing $1 \mathrm{~cm}^{2}$ of soil from the surface and from a $3 \mathrm{~cm}$ depth and dipping the sample into water chambers. The stability assessment used the classification proposed by Herrick et al. (2001).

One composite soil sample (surface to $3 \mathrm{~cm}$ depth) consisting of 10 subsamples sampled every $5 \mathrm{~m}$ was collected along the central transect for use in all subsequent laboratory tests (Grondin and Johansen, 1993). An additional composite sample of surface soil only (surface to $1 \mathrm{~cm}$ depth) was taken by sampling $10 \mathrm{~cm}$ away from each of the composite (surface to $3 \mathrm{~cm}$ depth) samples. The first composite sample was subsequently used for determination of soil characteristics, while the second was reserved for examination of soil algae.

In addition to the quantitative crust abundance data taken at the 75 sites as described above, a visual assessment of each site was made by walking over the area and assigning it to a single crust cover category. We developed a categorical classification system to describe microbiotic soil crusts using the dominant community members and the crust's relative development (according to relative crust patch size and crust stability in response to mechanical shaking by hand). Categories included: 1) 0 for absence of crust or presence of only incipient crust; 2) A1, A2, A3 for algal crust, with 1, 2 , and 3 representing increasing development. A1 had crust scattered in an area less than $5 \mathrm{~m}^{2}$, A2 was characterized by crust patches scattered over an area of greater than $5 \mathrm{~m}^{2}$ but not more than $10 \mathrm{~m}^{2}$, and $\mathrm{A} 3$ had blackened crust covering an extensive area greater than $10 \mathrm{~m}^{2}$ with algae more visible than lichens; 3) L1, L2, L3 for lichen crust (algae were also usually present) with 1, 2, and 3 representing increasing development. The lichen categories used the same scoring scheme for algae given above; 4) M1, M2, M3 for the crusts containing mosses (algae and lichens were also usually present). In M1, moss had to be present in at least one patch in an 
area less than $5 \mathrm{~m}^{2}$. M2 and M3 were scored in the same manner as for algal and lichen crusts.

In addition to the 75 established intensively sampled plots described above, we also applied the visual assessment categories $(0, A 1, A 2$, etc.) to 140 other sites visited while hiking through the wilderness areas and noting presence or absence of visual crust cover. Most of these sites were selected because we noted some evidence of soil crusts. However, some sites with no visually apparent crusts (with no soil surface consolidation) also were included during our surveys.

\subsection{Laboratory analyses}

Composite soil samples collected in the field were air dried overnight. After drying, samples were sieved $(2 \mathrm{~mm})$ to separate gravel from the fine earth fraction. Litter was removed, and microbiotic soil crust aggregates were pressed through the $2 \mathrm{~mm}$ mesh to separate soil particles from soil organic matter. Total gravel content was determined gravimetrically from the total weight of the sample.

Percentage of sand, silt and clay was determined using a modified Bouyoucos hydrometer method (Gee and Or, 2002) with the following modifications: from each sample $90 \mathrm{~g}$ of air dried fine earth was soaked for $24 \mathrm{~h}$ with $50 \mathrm{ml}$ of $10 \%$ sodium hexametaphosphate to enhance soil dispersion. The sample was than mixed for 5 min with a conventional shake mixer. Sand fractions of very coarse sand, coarse sand, medium sand, fine sand and very fine sand were determined with the recovered sand from the hydrometer analysis. This work was conducted using standard sand sieves by the Soil Testing Laboratory at Brigham Young University, UT.

To determine soil $\mathrm{pH}$ and electrical conductivity (EC), saturated soil pastes were prepared following the method described in the USDA Handbook No. 60 (U.S. Salinity Laboratory Staff, 1954). For each sample, $200 \mathrm{~g}$ soil was combined with deionized water until it yielded a paste-like consistency. Measurements were taken $12 \mathrm{~h}$ later.

\subsection{Statistics}

Data from the 75 intensively studied sites provided the basis for all statistical analyses. Descriptive statistics for microbiotic crust abundance measures and correlations between soil stability, surface gravel and total crust cover were calculated ( $R$ 2.6.1, R Development Core Team, Vienna, Austria). Canonical Correspondence Analysis (CCA) was used to relate crust functional groups to biotic and abiotic variables (e.g., plant functional groups and physical factors) using both frequency and cover data (CANOCO 3.1, Centre for Biometry, Wageneningen, The Netherlands). Data on developmental stages of algal crust were missing for four sites; thus samples from these sites were omitted from the CCA analysis. Explanatory (i.e., independent) variables used for the frequency CCA were: elevation, particle size including sand fractions, $\mathrm{pH}$, EC, desert type, presence of grusy granitic soils, presence of desert pavement, percent frequency of woody shrubs, cacti, perennials, rocks, and presence of granitic boulders or exposed bedrock. The following functional/taxonomic groups were included as dependent variables: incipient crust, unblackened algal crust, blackened algal crust, Collema spp., Peltula spp., Placidium sp., Psora luridella, unknown cyanobacterial lichen (Heppia sp. or Peltula sp.), and moss crust. Explanatory variables used for the cover CCA were: elevation, particle size including sand fractions, $\mathrm{pH}, \mathrm{EC}$, presence of grusy granitic soils, presence of desert pavement, and desert type. Percent frequencies of woody shrubs, cacti, perennials, rocks, and boulder/ bedrock was not used as explanatory variables for cover data due to their methodological restrictions for frequency data only. The dependent variables were the same as for the frequency CCA. A Monte Carlo Permutation test with 499 permutations was used to test for significance of the dependent variables $(P>0.05)$. All environmental factors plotted were significant $(P \leq 0.05)$.

\section{Results}

\subsection{Visual microbiotic crust assessments}

Microbiotic crust development was confined strictly to depositional soils of the wilderness areas. Although we detected lichens and mosses growing in soil mountain slopes at a few sites, they typically were restricted to the small colluvial soil accumulations on the shady side of rocks and did not have sufficient development to be designated as "crusts". By definition, a crusted site had to have surface soil to support microbiotic crusts. Areas of extensive crust development and richness of morphological crust groups were found mainly in the granitic landscapes scattered throughout the park. These sites were dominated by our crust cover classes A3, L3, and M3, indicating welldeveloped, individual crust patches $>10 \mathrm{~m}^{2}$. In regions with grusy granitic soils, crust cover was $\geq 35 \%$. Surprisingly, many areas of high crust diversity and visual cover were also in areas that have experienced moderate disturbance levels (e.g., areas near former grazing lands in the northwestern and southern portion of the park).

Throughout JTNP, microbiotic crust was detected in 66\% of the frequency plots assessed (7500 $1 \mathrm{~m}^{2}$ quadrats in all), with the percent frequency for individual sites ranging from 6 to $100 \%$. Algal crust was most common, being found in $\approx 65 \%$ of the plots (Table 1 ). Incipient crust and unblackened crust were found in $\approx 30 \%$ of all plots. Lichen crust was detected in only $17 \%$ of the plots. Cyanobacterial lichen was found over twice as often as green algal lichen. Collema dominated the lichen crust (Table 1). Blackened crust, moss, and mixed crust were the most rare categories (Table 1 ).

\section{Table 1}

Mean absolute and relative percent cover as well as frequency for scored crust abundance categories, vascular plants abundance categories, and physical land surface categories in JTNP, CA. Relative cover was calculated as soil surface present without cover of any physical land surface components (no gravel, cobbles, rock and boulders). All cover values in subcategories sum to the value for their associated main category. Frequency values generally do not sum in a similar fashion due to the possibility of scoring presence of various subcategories in the same plot. Developmental subcategories of algal crust frequency sum because highest developmenta stage was scored. Data are means (S.E.) $(n=71-75)$.

\begin{tabular}{lccc}
\hline Abundance & $\begin{array}{c}\text { Average absolute } \\
\text { cover }(\%)\end{array}$ & $\begin{array}{l}\text { Average relative } \\
\text { cover }(\%)\end{array}$ & $\begin{array}{l}\text { Average } \\
\text { frequency }(\%)\end{array}$ \\
\hline Total crust & $13.1(1.6)$ & $20.2(2.3)$ & $65.7(3.1)$ \\
Algal crust & $11.4(1.3)$ & $17.4(1.8)$ & $64.7(3.1)$ \\
$\quad$ Incipient crust & $4.1(0.5)$ & $6.9(0.8)$ & $28.9(2.2)$ \\
Unblackened crust & $5.7(1.0)$ & $8.4(1.4)$ & $26.6(2.7)$ \\
Blackened crust & $1.0(0.3)$ & $1.7(0.5)$ & $9.8(2.1)$ \\
Lichen crust & $1.7(0.5)$ & $2.7(0.7)$ & $17.3(2.9)$ \\
Cyanobacteria lichen & $1.5(0.4)$ & $2.3(0.7)$ & $16.2(2.8)$ \\
$\quad$ Collema spp. & $0.9(0.3)$ & $1.3(0.4)$ & $13.1(2.6)$ \\
$\quad$ Peltula spp. & $0.2(0.1)$ & $0.3(0.1)$ & $5.6(1.2)$ \\
$\quad$ Unknown spp. & $0.4(0.2)$ & $0.7(0.3)$ & $8.5(1.9)$ \\
Green algae lichen & $0.2(0.1)$ & $0.4(0.1)$ & $7.0(1.7)$ \\
$\quad$ Placidium squam. & $0.2(0.1)$ & $0.4(0.1)$ & $7.0(1.7)$ \\
$\quad$ Psora spp. & $0.0(0)$ & $0.0(0)$ & $0.03(0.02)$ \\
Moss crust & $0.02(0.02)$ & $0.02(0.02)$ & $1.0(0.4)$ \\
Mixed crust & $0.07(0.04)$ & $0.1(0.05)$ & $0.5(0.4)$ \\
Woody shrubs & $13.0(1.3)$ & $21.4(2.0)$ & $37.0(2.8)$ \\
Perennial plants & $1.5(0.3)$ & $2.5(0.5)$ & $17.6(2.5)$ \\
Cacti & $0.2(0.1)$ & $0.4(0.1)$ & $2.5(0.5)$ \\
Annuals & $12.4(1.6)$ & $18.8(2.0)$ & - \\
Litter & $12.6(0.8)$ & $21.1(1.4)$ & - \\
Bare soil & $11.0(1.8)$ & $15.6(2.1)$ & - \\
Gravel & $21.6(1.5)$ & - & - \\
Cobbles & $9.7(1.5)$ & - & - \\
Rocks & $3.9(0.8)$ & - & $29.1(4.0)$ \\
Boulder & $0.9(0.3)$ & - & $3.8(1.2)$ \\
\hline
\end{tabular}


Total microbiotic crust in studied areas of JTNP had an absolute mean ground cover (based on the point-line intercept method) of $13.1 \% \pm$ SE 1.6 and ranged from $<0.4 \%$ to $61.2 \%$. Average relative crust cover as the relative portion of soil surface available for crust establishment was $20.2 \% \pm$ SE 2.2 and ranged from $0 \%$ to $82.7 \%$. The remaining soil surface portion (omitting cover of physical land surface components such as rocks) was occupied by vascular plants (43.2\% \pm SE 2.5), litter (21.1\% \pm SE 1.4), and bare soil (15.6\% \pm SE 2.1).

The majority of the crust was composed of algal crust (Table 1). Within the algal crust, the category unblackened algal crust had the greatest mean cover, followed by incipient crust. Blackened algal crust, moss and lichen crusts were minor components of ground cover (Table 1). However, cyanobacterial lichen crust could reach a maximum absolute cover of $25.2 \%$ in some sites, which was over ten times greater than the maximum cover of absolute green algal lichen crust (2.4\%). Considering relative cover, cyanobacterial lichen crust covered about seven times (32.0\%) more soil than green algal lichen crust (4.5\%). Moss crust was only detected once using cover methods and had a very low absolute and relative mean cover (Table 1 ) as well as a limited distribution.

\subsection{Visual assessment of non-crust land surface features}

Perennial plant cover categories (woody shrubs, perennial plants, and cacti) had relatively low frequencies (Table 1 ). Annual vascular plants and plant litter were found at nearly all sites within the wilderness areas studied and consequently were not quantified with respect to frequency. Vascular plants covered a total of $27 \%$ (absolute cover) of the area, with about half the cover due to woody shrubs and half due to non-woody, annual plants (Table 1). Physical land features (bare soil, rocks, etc.) contributed a total absolute mean cover of $\approx 47 \%$ and thus dominated the surface of the landscape at JTNP.

\subsection{Soil properties}

Surface soil texture could be classified as ranging from silt loam to sand (Schoeneberger et al., 2002), although sandy soils were clearly most extensive. Percent sand ranged from 45.3 to $94.0 \%$. Silt varied from 4.5 to $50.2 \%$. Clay was generally low, with values between 1.1 and $8.9 \%$. Of all 75 soil samples, 57 had soil gravel contents above $15 \%$ and thus were gravelly $(>15-<35 \%$ ) or very gravelly ( $>35-60 \%)$.

Mean soil pH was $7.4 \pm$ SE $0.05(n=75)$, with values varying from slightly acidic to alkaline ( $\mathrm{pH}$ 5.9-8.2). Mean E.C. was $779 \pm$ SE $81.6(n=75)$, with values varying from 232 to $5210 \mu \mathrm{S} \mathrm{cm}^{-1}$. In general, very fine silty soils had higher $\mathrm{pH}$ and EC values than other soil types. Soil stability showed only a weak correlation with total crust cover $\left(R^{2}=0.41, P=0.0002\right)$.

\subsection{Relationships among microbiotic crust types and explanatory variables}

According to both our frequency and cover data, well-developed crusts (blackened crust, various lichen crusts), poorly developed crusts, and the rare crust categories including moss crusts were associated with different explanatory variables (Figs. 3 and 4 , Table 2). Proximity to granite outcrops, as evidenced by the presence of grusy granitic soils as well as the presence of granitic boulders or exposed bedrock were associated with moss and mixed crust abundance, as well as with the rare lichen P. luridella (Fig. 3). Cyanolichen and blackened algal crusts (both with cyanobacteria capable of fixing nitrogen) were associated with gravel, coarse sand, and fine sand, as well as presence of boulders and grusy granitic soils (Figs. 3 and 4). Higher elevation sites had relatively less developed crusts (Figs. 3 and 4).

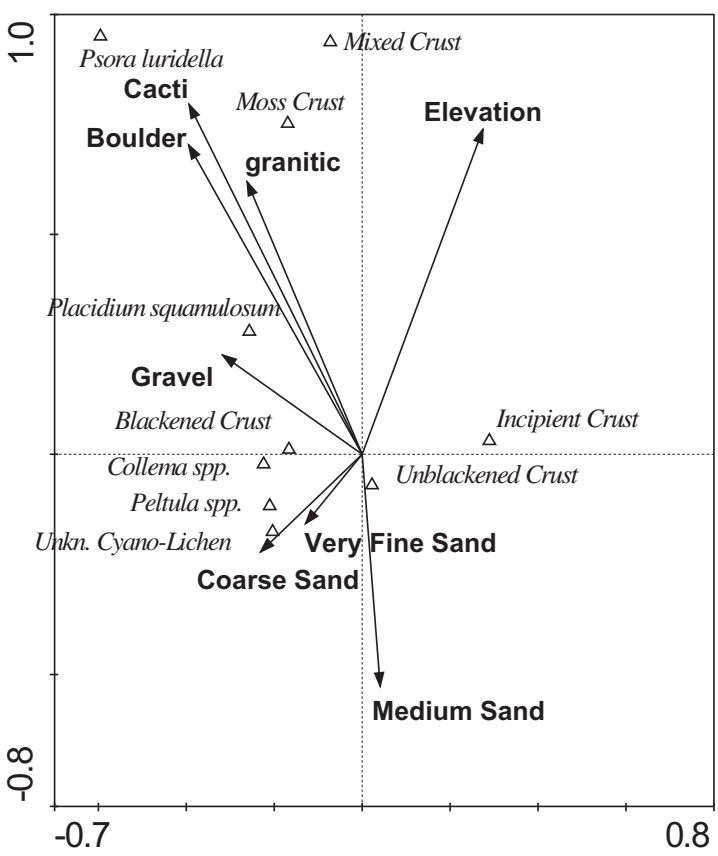

Fig. 3. CCA biplot for microbiotic crust frequency data showing significant explanatory variables only. The first two axes describe a total of $82.0 \%$ of the explainable variability in the data. The first axis (horizontal) described $55.7 \%$ of the species-environment relation (canonical eigenvalue $=0.25$ ) and the second axis (vertical), 26.3\% (canonical eigenvalue $=0.12$ )

Relationships between explanatory variables and unblackened algal crust and incipient algal crust could not be discerned with the frequency data, as both crust types plotted near the origin (Fig. 3). In contrast, more clear relationships between the explanatory

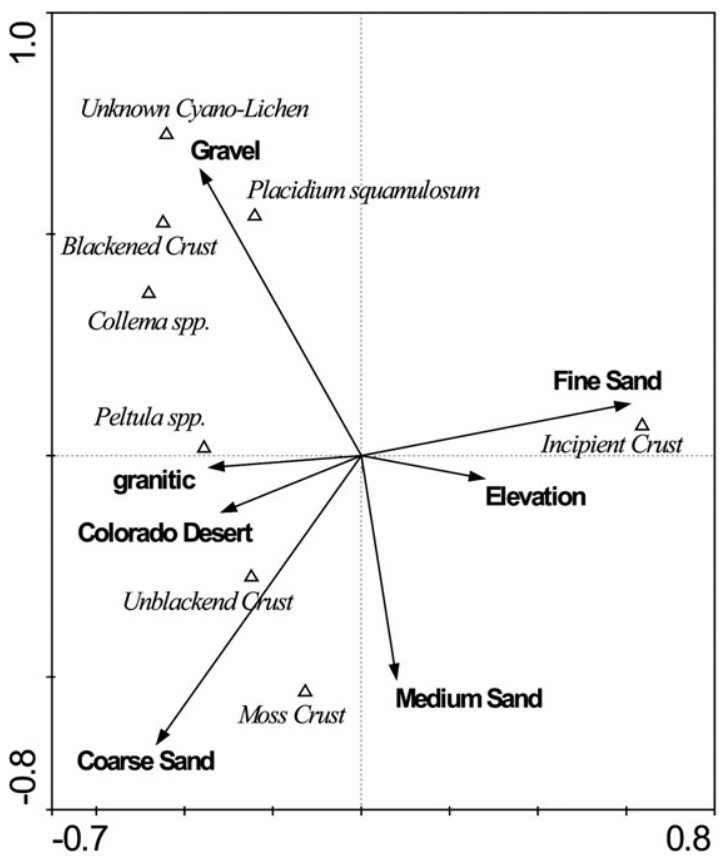

Fig. 4. CCA biplot for microbiotic crust cover data showing significant explanatory variables only. The first two axes describe a total of $81.1 \%$ of the explainable variability in the data. The first axis (horizontal) described $55.9 \%$ of the species-environment relation (canonical eigenvalue $=0.21$ ) and the second axis (vertical), 25.2\% (canonical eigenvalue $=0.08$ ) 
Table 2

Significant explanatory variables for the CCA models using microbiotic crust frequency (total inertia $=1.07$ ) and cover (total inertia $=1.01$ ) data. Presented are $P$-values (F-ratios) associated with each variable (n.s. $=$ not significant).

\begin{tabular}{lll}
\hline Explanatory variable & Frequency data & Cover data \\
\hline Presence of granitic boulder & $0.036(3.08)$ & $\mathrm{N} / \mathrm{A}$ \\
Presence of grusy, granitic soil & $0.032(2.52)$ & $0.022(4.14)$ \\
Gravel content & $0.008(3.81)$ & $0.002(6.46)$ \\
Coarse sand & $0.002(9.58)$ & $0.024(2.39)$ \\
Medium sand & $0.002(5.18)$ & $0.036(2.58)$ \\
Fine sand & n.s. & $0.002(6.22)$ \\
Very fine sand & $0.016(4.63)$ & $0.058(3.50)$ \\
Elevation & $0.002(8.38)$ & $0.002(6.46)$ \\
Sonoran Desert & n.s. & $0.024(3.32)$ \\
Presence of cacti & $0.002(8.26)$ & $\mathrm{N} / \mathrm{A}$ \\
\hline
\end{tabular}

variables and the widely abundant incipient and unblackened crust classes were more apparent using cover data (Fig. 4). Incipient crust was associated with high elevation and even more closely aligned with fine sand. Unblackened crust was associated with coarse sand. The cover data also indicated that well-developed cyanolichen and blackened algal crusts were associated not only with grusy granitic soil and gravel cover but also the Colorado Desert.

Not all environmental variables included in our CCA models were important drivers of crust distribution and abundance, as determined by Monte Carlo permutation tests. Very coarse sand, silt, clay, presence of desert pavement, $\mathrm{pH}$, and EC were not statistically significant drivers for the cover and frequency models. Additionally, for the frequency model only, woody shrubs, perennial plants, rocks, and desert type were not statistically significant.

\section{Discussion}

\subsection{Comparison of microbiotic crust distribution with other desert regions}

At a regional scale, the crusts of Joshua Tree National Park are limited in their distribution based on absolute and relative cover data, particularly for moss and lichen crusts. Compared to the cold deserts of North America, in which microbiotic crusts are visually abundant and widespread (Evans and Johansen, 1999; Belnap, 2002; Rosentreter and Belnap, 2003), considerable crust patchiness and low overall ground cover were observed in this and previous studies of the Mojave Desert (Johansen et al., 2001; Belnap, 2002; Pietrasiak, 2005; Thompson et al., 2005). Climatically, the deserts of JTNP differ greatly from the cold deserts, with higher mean annual temperatures and lower mean annual precipitation (Johansen, 1993). Additionally, unlike the cold deserts in which soil moisture is recharged predictably each spring from snow melt, precipitation is more pulsed and unpredictable in the hot deserts, such as the Mojave and Colorado Deserts (Osborn, 1983). Soil moisture deficiency could be one of the most important factors contributing to their limited distribution, particularly for mosses and lichen crust types.

Similar to other Mojave Desert sites (Johansen et al., 2001; Belnap et al., 2007a) the most prevalent crusts were incipient and unblackened crusts, the least well-developed crust types. Welldeveloped crusts containing algal, lichen and moss crust types were confined to grusy granitic soils, although they can be locally abundant on these soil types (35-50\% absolute cover; Pietrasiak, 2005). Moss and green algal lichen crust were very rare components of the park and were strictly limited to these grusy granitic soil habitats.

\subsection{Factors driving microbiotic crust distribution}

Physical factors, such as soil texture, also seem to impede more prolific crust establishment in JTNP. Most soils in JTNP are very sandy, and our most poorly developed crusts often were associated with sandy soils. Many studies have shown the general negative effect of increasing sand proportion on crust cover due to its low water holding capacity (Kleiner and Harper, 1972, 1977; Anderson et al., 1982a,b; Belnap, 2002; Eldridge et al., 2006). However, even in areas with finely textured soils in JTNP, crust establishment was patchy. This result contrasts with previous work in the Great Basin (cold desert; Anderson et al., 1982a) and Sonoran (hot desert; Belnap, 2002), in which crust establishment was most pronounced in areas with finely textured soils. Two factors likely precluded crust development in finely textured soils in our study. First, finely textured soils often were associated with desert pavement, where surface gravel and rock cover was so high that surface area available for crust was minimal. Secondly, although potential water holding capacity in finely textured soils can be high (Brady and Weil, 2002), low and inconsistent precipitation likely prevent sufficient moisture recharge for crusts to establish in these areas.

As revealed by the CCA analysis, it is apparent that a suite of factors unique to the Mojave and Colorado Deserts play a role in the development of microbiotic crust and deviation from that set of conditions may inhibit crust establishment. Overall, only abiotic factors (e.g., grusy granitic soils, percent coarse sand, and percent gravel) significantly influenced the soil crust community distribution pattern in JTNP. Although the biotic factors selected in this study did not show a detectable influence on total crust and crust functional group abundance, other studies have shown relationships of specific plant species with crust types (Johansen et al., 1981; Maestre et al., 2002; Maestre and Cortina, 2002; Maestre, 2003; Thompson et al., 2005; Thomas and Dougill, 2006). These discrepancies could be contributed to the spatial extent of the study; our work surveyed microbiotic crusts at the landscape-level, while studies showing relationships with plant species focused on much smaller spatial extents $\left(<100 \mathrm{~m}^{2}\right)$.

The most important predictor for crust abundance and distribution was geologic bedrock composition, which serves as parent material for surrounding soils. All highly significant $(P \leq 0.01)$ factors in both biplots (i.e., elevation and physical soil variables) were associated with geology. The elevation gradient indicates the sequence of metamorphic, granitic and alluvial landforms of the park, with metamorphic forming the highest and rockiest mountains. Similar to other studies in the Mojave Desert (Thompson et al., 2005), elevation and crust cover were negatively related in JTNP, although one of the areas with greatest crust cover was located at higher elevation (Wonderland of Rocks). Soil physical properties (sand fractionation and percent soil gravel) distinguished soils originating from the mesozoic granitic parent material, as soil derived from granite has a high degree of soil gravel. Due to its characteristic mineralogy, granite disintegrates into a gravelly to sandy sediment designated as grus (Thomas and Goudie, 2000; Neuendorf et al., 2005). Presence of grusy granitic soils, granitic boulder frequency and desert type (i.e., Mojave or Colorado) were significant explanatory variables in one or both biplots, and all areas with well-developed crust mapped to areas with Mesozoic granitic bedrock in both deserts (Table 2). Granitic landscapes may provide a more favorable environment due to their greater fragmentation (finer sands and gravels), lower soil temperatures in the summer (due to their light coloration and higher albedo), and potentially higher soil moisture availability.

Sites in close proximity to granitic bedrock also had higher crust functional group richness. Several green algal lichens and even moss crusts were noticeable in such sites. In a previous study at JTNP, granitic soils supported higher moss and lichen cover compared to other soil types (Pietrasiak, 2005). Mosses require moister and cooler climatic conditions than other crust types (Martinez et al., 2006; Belnap et al., 2003). In our study, these crust types were associated with increasing granitic boulder frequency. 
Shading by boulders may decrease evapotranspiration (Martinez et al., 2006) and thus may provide more suitable microclimatic conditions for lichens and mosses. In granitic landscapes, shallow soil pockets also may provide a higher water table, improving soil moisture availability. Greater available moisture lengthens the hydration periods for lichens and algae, thus potentially enhancing photosynthetic activity and reducing carbon loss (Jeffries et al., 1993; Eldridge, 1996; Lange et al., 1998; Evans and Johansen, 1999). Crust species also may benefit from the gravelly structure of grusy granitic soils, which easily capture dust. With an increase in fine particles, water holding capacity (Belnap, 2002), cation exchange capacity, and moisture availability can be enhanced at the microscale (Brady and Weil, 2002). In the Namib Desert, gravel was suggested to function as collection traps for lichen fragments (Lalley and Viles, 2006), potentially enhancing crust growth and development. In addition, during rainfall events the granitic grus might function as micro-watersheds, increasing the amount of water contributed to small soil interspaces at this microscale.

In contrast to granitic sites, only the cyanolichens Collema spp., Peltula spp. and Heppia sp. were found on piedmont slopes and basins in JTNP. These open spaces are constantly exposed to high radiation and experience long periods of drought (Evans and Johansen, 1999). Currently, it is unclear which traits support successful cyanolichen establishment under these stressful environmental conditions. In our study, and consistent with the findings of Johansen et al. (2001), the lichens were all dark and blackish in color. This is different from the lichen crusts of the Great Basin and Colorado Plateau, in which white, light green, yellow, and rose-colored lichens also occur frequently as a component of the flora, in addition to the dominant dark-colored lichens. Studies with lichens suggest dark pigmentation may provide some photoprotection (Belnap et al., 2001, 2007b). Alternatively, dark coloration (due to its lower albedo) may warm soils during winter months when water is available. Future work should focus on relating morphological and physiological traits to stress tolerance in these cyanolichens.

\subsection{Microbiotic crust and soil stabilization}

One of the most important ecological functions of microbiotic crusts is thought to be soil surface stabilization, which reduces soil erosion (Evans and Johansen, 1999). However, in JTNP microbiotic crusts correlated only weakly with soil stability at the regional scale. This weak correlation can be explained by the presence of physicochemical (i.e., non-biological) crusts and/or higher vascular plant cover in areas lacking microbiotic crusts. Both non-biological crusts and shallow rooting vascular plants can contribute to soil consolidation, raising the stability index (Eldridge and Leys, 2003). Gravelly soil structure also reduces the role of microbiotic crusts in preventing soil surface erosion. Increased rock and gravel cover and elevated subsurface stability can significantly increase wind erosion resistance in the granitic soils of the Mojave Desert (Belnap et al., 2007a). Therefore, microbiotic crusts in JTNP likely do not serve a primary role in soil surface stabilization.

\subsection{Summary and implications for land management}

In summary, microbiotic crusts of the Mojave Desert are limited in their distribution compared to crusts of other arid regions of North America based on visual relative and absolute abundance data (see Belnap, 2002; Baskin et al., 2003; Rosentreter and Belnap, 2003). The edaphic drivers of soil crust development in cold deserts, such as the Great Basin and Colorado Plateau, did not have a detectable influence on crust development in the hot deserts of JTNP. In this study, well-developed crusts were associated with grusy, granitic soils near granitic bedrock and outcrops rather than finely textured silts and clays. Other factors implicated as important in crust development in other regions, such as soil $\mathrm{pH}$ and EC were minimally important in directly determining crust development in JTNP, as evidenced by the CCAs. Although these factors can be linked to the underlying geology of the site, they were insignificant in driving community structure. Likewise, specific plant type did not influence crust establishment. Instead, crusts were associated with a suite of factors that could ameliorate the stressful climatic conditions of these hot deserts, by potentially improving soil moisture availability, decreasing radiation (and thus air temperature), or both. In those areas not supporting crusts (no visual appearance and soil surface consolidation), we suggest that crust development may be impeded by unsuitable habitat conditions, since the wilderness areas included in our study have experienced minimal anthropogenic disturbance for many decades. Consequently, some areas of the Mojave Desert (including JTNP) may be incapable of supporting significant microbiotic crust, even in the absence of anthropogenic disturbance, although the specific factors preventing more prolific establishment are not definitively known.

Given the limited distribution of biological soil crusts in this study, those with stewardship responsibility for public lands should recognize that crusted sites in hot deserts, such as the Mojave and Colorado Deserts, are rare communities that deserve special protection and management efforts. This study should provide guidance as to the factors influencing crust distribution and abundance in these landscapes, with geology being an important driver. Stressful conditions, such as limiting precipitation and high temperatures likely prevent more abundant crust establishment in these hot desert environments. Together, the distinctive drivers of these communities and distribution pattern of crusts in these sites make them unique and interesting communities worthy of future study and protection.

\section{Acknowledgements}

We would like to thank the National Park Service for permission to work within the JTNP and their logistic support. We greatly acknowledge Charla Wade, Student Conservation Association participant Rhea Rhaman and National Park personnel for assistance with field work. Lichen identification was confirmed by K. Knudsen. Vascular plant identification was assisted by $\mathrm{T}$. LaDoux and M. Bell. The authors would also like to acknowledge M. Nichols for assistance with electric conductivity and $\mathrm{pH}$ measurements. Funding for field survey was provided by the The California Desert Research Fund at The Community Foundation. Graduate student assistant support as well as support for publication costs were provided by John Carroll University. We would like to thank the anonymous reviewers for their insightful suggestions and evaluations of the manuscript.

\section{References}

Anderson, D.C., Harper, K.T., Holmgren, R.C., 1982a. Factors influencing development of cryptogamic soil crusts in Utah Deserts. Journal of Range Management 35, $180-185$.

Anderson, D.C., Harper, K.T., Rushforth, S.R., 1982b. Recovery of cryptogamic soil crust from grazing on Utah winter ranges. Journal of Range Management 35, 355-359.

Baskin, M., Stohlgren, T.J., Otsuki, Y., Lee, M., Evangelista, P., Belnap, J., 2003. Soil characteristics and plant exotic species invasions in the Grand Staircase Escalante National Monument, Utah, USA. Applied Soil Ecology 22, 67-77.

Belnap, J., Kaltenecker, J.H., Rosentreter, R., Williams, J., Leonard, S., Eldridge, D.J., 2001. Biological Soil Crusts. Ecology and Management. TR-1730-2. US Department of the Interior, Denver, CO, USA, $110 \mathrm{pp}$.

Belnap, J., 2002. Impacts of off-road vehicles on nitrogen cycles in biological soil crusts: resistance in different U.S. deserts. Journal of Arid Environments 52, 155-165.

Belnap, J., Büdel, B., Lange, Q.L., 2003. Biological soil crust: characteristics and distribution. In: Belnap, J., Lange, O.L. (Eds.), Biological Soil Crusts: Structure, 
Function, and Management. Springer Verlag, Berlin, Germany, pp. 3-30. revised second print.

Belnap, J., Lange, O.L., 2003. Preface. In: Belnap, J., Lange, O.L. (Eds.), Biological Soil Crusts: Structure, Function, and Management. Springer Verlag, Berlin, Germany, pp. $\mathrm{v}-\mathrm{ix}$. revised second print.

Belnap, J., Phillips, S.L., Herrick, J.E., Johansen, J.R., 2007a. Wind erodibility of soils at Fort Irwin, California (Mojave Desert), USA, before and after trampling disturbance: implications for land management. Earth Surface Processes and Landforms 32, 75-84.

Belnap, J., Phillips, S.L., Smith, S., 2007b. Dynamics of cover, UV-protective pigments, and quantum yield in biological soil crust communities of an undisturbed Mojave Desert shrubland. Flora 202, 674-686.

Brady, N.C., Weil, R.R., 2002. The Nature and Properties of Soils, thirteenth ed Prentice Hall, Upper Saddle River, New Jersey, USA, 960 pp.

Darby, B.J., Neher, D.A., Belnap, J., 2007. Soil nematode communities are ecologically more mature beneath late than early-successional stage biological soil crusts. Applied Soil Ecology 35, 203-212.

Eldridge, D.J., 1996. Distribution and floristics of terricolous lichens in soil crusts in arid and semi-arid New South Wales, Australia. Australian Journal of Botany 44, 581-599.

Eldridge, D.J., Leys, J.F., 2003. Exploring some relationship between biological soil crusts, soil aggregation and wind erosion. Journal of Arid Environments 53, 457-466.

Eldridge, D.J., Freudenberger, D., Koen, T.B., 2006. Diversity and abundance of biological soil crust taxa in relation to fine and coarse-scale disturbance in a grassy eucalypt woodland in eastern Australia. Plant and Soil 281, 255-268.

Evans, R.D., Johansen, J.R., 1999. Microbiotic crusts and ecosystem processes. Critical Reviews in Plant Sciences 18, 183-225.

Gee, G.W., Or, D., 2002. Particle-size analysis. In: Dane, J.H., Topp, G.C. (Eds.), Methods of Soil Analysis. Part 4. SSSA Book Series, vol. 5. SSSA, Madison, WI, USA, pp. 255-293.

Greene, L.W., 1983. Historic resource study: A history of land use in Joshua Tree National Monument. Unpublished report to the Joshua Tree National Park Service. U.S. Department of Interior, Denver, CO, USA.

Grondin, A.E., Johansen, J.R., 1993. Microbial spatial heterogeneity in microbiotic crusts in Colorado National Monument. I. Algae. Great Basin Naturalist 53, 24-30.

Herrick, J.E., Whitford, W.G., de Soyza, A.G., Van Zee, J.W. Havstad, K.M. Seybold, C.A., Walton, M., 2001. Field soil aggregate stability kit for soil quality and rangeland health evaluations. Catena 44, 27-35.

Jeffries, D.L., Link, S.O., Klopatek, J.M., 1993. $\mathrm{CO}_{2}$ fluxes of cryptogamic crusts. II. Response to dehydration. New Phytologist 125, 391-396.

Johansen, J.R., Rushforth, S.R., Brotherson, J.D., 1981. Subaerial algae of Navajo National Monument, Arizona. Great Basin Naturalist 41, 433-439.

Johansen, J.R., 1986. Soil algae and range management. Applied Phycology 3, 1-2.

Johansen, J.R., 1993. Cryptogamic crusts of semiarid and arid lands of North America. Journal of Phycology 29, 140-147.

Johansen, J.R., Britton, C., Rosati, T.C., Li, X., St. Clair, L.L., Webb, B.L., Kennedy, A.J., Yanko, K.S., 2001. Microbiotic crust of the Mojave Desert: factors influencing distribution and abundance. In: Elster, J., Seckbach, J., Vincent, W.F., Lhotský, O. (Eds.), Algae and Extreme Environments. Proceedings of the International Conference, Třeboň, Sept. 2000, vol. 123. Nova Hedwigia, Beiheft, pp. 341-371.

Johansen, J.R., Schubert, L.E., 2001. Algae in Soils, vol. 123. Nova Hedwigia, Beiheft. 297-306

Kleiner, E.F., Harper, K.T., 1972. Environment and community organization in grasslands of Canyonlands National Park. Ecology 53, 299-309.

Kleiner, E.F., Harper, K.T., 1977. Soil properties in relation to cryptogamic groundcover in Canyonlands National Park. Journal of Range Management 30, 202-205.

Lalley, J.S., Viles, H.A., 2006. Do vehicle track disturbances affect the productivity of soil-growing lichens in a fog desert? Functional Ecology 20, 548-556.
Lange, O.L., Belnap, J., Reichenberger, H., 1998. Photosynthesis of the cyanobacterial soil-crust lichen Collema tenax from arid lands in southern Utah, USA: role of water content on light and temperature responses of $\mathrm{CO}_{2}$ exchange. Functional Ecology 12, 195-202.

MacMahon, J.A., Wagner, F.H., 1985. The Mohave, Sonoran, and Chihuahuan deserts of North America. In: Evenari, M., Noy-Meir, I., Goodall, D.W. (Eds.), Hot Deserts and Arid Shrublands, vol. 12a. Elsevier Science Publishers, Amsterdam, Netherlands, pp. 105-202.

Maestre, F.T., Cortina, J., 2002. Spatial pattern of surface soil properties and vegetation in a Mediterranean semi-arid steppe. Plant and Soil 241, 279-291.

Maestre, F.T., Huesca, M., Zaady, E., Bautista, S., Cortina, J., 2002. Infiltration, penetration resistance and microphytic crust composition in contrasted microsites within a Mediterranean semi-arid steppe. Soil Biology \& Biochemistry $34,895-898$.

Maestre, F.T., 2003. Small-scale spatial patterns of two soil lichens in semi-arid Mediterranean steppe. Lichenologist 35, 71-81.

Martinez, I., Escudero, A., Maestre, F.T., de la Cruz, A., Guerrero, C., Rubio, A., 2006 Small-scale patterns of abundance of mosses and lichens forming biological soil crusts in two semi-arid gypsum environments. Australian Journal of Botany 54, 339-348.

Neuendorf, K.K.E., Mehl Jr., J.P., Jackson, J.A. (Eds.), 2005. Glossary of Geology, fifth ed. American Geological Institute, Washington, D.C., USA, p. 800.

Osborn, H.B., 1983. Timing and duration of high rainfall rates in southwestern United States. Water Resources Research 19, 1036-1042.

Pietrasiak, N., 2005. Spatial assessment of microbiotic soil crust in high vs. low recreational use areas within the Wonderland of Rocks of Joshua Tree National Park, California. Thesis, Leipzig, Germany, University of Leipzig. 94 p.

Řeháková, K., Johansen, J.R., Casamatta, D.A., Xuesong, L., Vincent, J., 2007. Morphological and molecular characterization of selected desert soil cyanobacteria: three species new to science including Mojavia pulchra gen. et sp. nov. Phycologia 46, 481-502.

Rosentreter, R., Belnap, J., 2003. Biological soil crusts of North America. In: Belnap, J., Lange, O.L. (Eds.), Biological Soil Crusts: Structure, Function, and Management. Springer Verlag, Berlin, Germany, pp. 31-50. revised second print.

Schoeneberger, P.J., Wysocki, D.A., Benham, E.C., Broderson, W.D. (Eds.), 2002. Field Book for Describing and Sampling Soils. Version 2.0. Natural Resources Conservation Service. National Soil Survey Center, Lincoln, NE, USA.

Shepherd, U.L., Brantley, S.L., Tarleton, C.A., 2002. Species richness and abundance patterns of microarthropods on cryptobiotic crusts in a piñon - juniper habitat: a call for greater knowledge. Journal of Arid Environment 52, 349-360.

Thomas, A.D., Dougill, A.J., 2006. Distribution and characteristics of cyanobacterial soil crusts in the Molopo Basin, South Africa. Journal of Arid Environment 64, 270-283.

Thomas, D.S.G., Goudie, A., 2000. The Dictionary of Physical Geography, third ed. Blackwell, Oxford, UK, 610 pp.

Thompson, D.B., Walker, L.R., Landau, F.H., Stark, L.R., 2005. The influence of elevation, shrub species, and biological soil crust on fertile islands in the Mojave Desert, USA. Journal of Arid Environments 61, 609-629.

Thompson, W.A., Eldridge, D.J., Bonser, S.P., 2006. Structure of biological soil crust communities in Callitris glaucophylla woodlands of New South Wales, Australia. Journal of Vegetation Science 17, 271-280.

U.S. Salinity Laboratory Staff, 1954. Diagnosis and Improvement of Saline and Alkal Soils. U.S. Department of Agriculture, Handbook 60, U.S. Gov. Print. Office, Washington, DC, USA, 160 pp.

West, N.E., 1990. Structure and function of microphytic soil crusts in wildland ecosystems of arid to semi-arid regions. Advances in Ecological Research 20, 45-53.

Zaady, E., Bouskila, A., 2002. Lizard burrows association with successional stages of biological soil crusts in an arid sandy region. Journal of Arid Environments 50, 235-246. 